\title{
Hubungan Antara Kandidiasis Pada urine Wanita Penderita Diabetes Mellitus Dengan Nilai Positivitas Glukosuria Di Wilayah Kerja Puskesmas Narmada
}

Fatima Az-zahro, Erna Kristinawati, Zainal Fikri,

Jurusan Analis Kesehatan, Poltekkes Kemenkes Mataram, Indonesia

\begin{tabular}{l} 
Article Info \\
Article history: \\
Received Jun $21^{\text {th }}, 2021$ \\
Revised Aug $25^{\text {th }}, 2021$ \\
Accepted Aug $26^{\text {th }}, 2021$ \\
\hline
\end{tabular}

Keyword:

Diabetes Mellitus,

Glucosuria,

Candidiasis

\begin{abstract}
Candidiasis in the female's genitalia can cause itching and vaginal discharge which is often considered a common and harmless thing. One of predisposing factor that can change the saprophytic properties of Candida sp. into a pathogen named diabetes mellitus. Hyperglycemia in uncontrolled diabetes mellitus causes glomerular filtration in the kidneys to contain more glucose than is reabsorbed so that glucosuria occurs. This study aims to determine the relationship between candidiasis in urine of women with diabetes mellitus and the value of glucosuria positivity in the working area of Narmada Health Center. This research is an Analytical Survey research with Cross Sectional design. The sample in this study amounted to 24 people. Urine samples in women with Diabetes Mellitus are examined for glucosuria first, then urine is centrifuged and observed for the presence of fungus causing Kandidiasis in its urine sediment. Based on examination of glucosuria and candidiasis, from 8 samplesof positive $(+1)$ glucosuria there was 1 positive sample of candidiasis, from 3 positive $(+2)$ glucosuria samples there were 2 positive candidiasis samples, and 13 other negative glucosuria and candidiasis samples. Chi square test results showed a significant relationship with a value of $p=0.007<0.05$. Statistically, there is a relationship between candidiasis in the urine of women with diabetes mellitus and the value of glucosuria positivity in the working area of the Narmada Health Center.
\end{abstract}

\begin{abstract}
ABSTRAK
Kandidiasis pada daerah kewanitaan dapat menyebabkan gatal dan keputihan yang sering dianggap sebagai hal yang umun dan tidak berbahaya. Salah satu faktor predisposisi yang dapat mengubah sifat saprofit Candida sp. menjadi patogen yaitu diabetes mellitus. Hiperglikemia pada penderita diabetes mellitus yang tidak terkontrol menyebabkan filtrasi glomerulus pada ginjal mengandung lebih banyak glukosa daripada yang direabsorpsi sehingga terjadi glukosuria. Penelitian ini bertujuan untuk mengetahui hubungan antara kandidiasis pada urine wanita penderita Diabetes Mellitus dengan nilai positivitas glukosuria di wilayah kerja Puskesmas Narmada. Penelitian ini merupakan penelitian Survei Analitik dengan rancangan Cross Sectional. Sampel dalam penelitian ini berjumlah 24 orang. Sampel urin pada wanita penderita Diabetes Mellitus diperiksa glukosurianya terlebih dahulu, kemudian urine disentrifuge dan diamati keberadaan jamur penyebab Kandidiasis pada sedimen urinnya. Berdasarkan pemeriksaan glukosuria dan kandidiasis, dari 8 sampel yang positif (+1) glukosuria terdapat 1 sampel positif kandidiasis, dari 3 sampel yang positif (+2) glukosuria terdapat 2 sampel yang positif kandidiasis, dan 13 sampel lainnya negatif glukosuria maupun kandidiasis. Hasil uji Chi square menunjukkan hubungan yang signifikan dengan nilai $\mathrm{p}=0,007<$ 0,05.Secara statistik, ada hubungan antara kandidiasis pada urine wanita penderita diabetes mellitus dengan nilai positivitas glukosuria di wilayah kerja Puskesmas Narmada.
\end{abstract}

Kata Kunci : Diabetes Mellitus, Glukosuria, Kandidiasis 


\section{Pendahuluan}

Kandidiasis adalah salah satu penyakit jamur yang bersifat akut atau subakut, disebabkan oleh jamur genus candida yang dapat mengenai mulut, vagina, kulit, kuku, bronki atau paru ${ }^{1}$. Setiap tahunnya, infeksi pada vagina menyerang perempuan di seluruh dunia $10-15 \%$ dari 100 juta perempuan, $15 \%$ diantaranya disebabkan oleh jamur candida. Pada wanita, kandidiasis dapat menyebabkan gatal dan keputihan. Keputihan atau kandidiasis genetalis sering dianggap sebagai hal yang umum dan dianggap tidak berbahaya ${ }^{3}$. Penyebab terbanyak kandidiasis adalah spesies Candida albicans (80-90\%). Beberapa faktor predisposisi dapat mengubah sifat saprofit Candida spp. menjadi patogen, antara lain : Diabetes Mellitus, penyalahgunaan antibiotik, penggunaan obat kortiokostreoid dan sitostatik, kehamilan, penggunaan pil anti hamil, dan kelembapan yang tinggi ${ }^{5}$. Dari hasil sebuah penelitian menyebutkan, diantara 76 orang wanita penderita Diabetes Mellitus terdapat 16 orang atau 21,05\% menderita Kandidiasis.

Penderita Diabetes Mellitus kemungkinan mengalami infeksi, karena mekanisme pertahanan alami tubuh pada orang yang menderita diabetes rendah ${ }^{7}$. Wanita penderita Diabetes Mellitus mempunyai gula ekstra dalam dinding vagina. Gula yang ada di urine tertumpuk pada vulva sehingga menyediakan makanan untuk pertumbuhan jamur. Daerah genetalia wanita adalah tempat subur dan ideal untuk pertumbuhan jamur sehingga pada urine wanita penderita Diabetes Mellitus kemungkinan besar ditemukan Candida albicans

Diabetes mellitus adalah penyakit metabolik yang umumnya bersifat herediter ditandai adanya hiperglikemia dan glukosuria dengan atau tanpa disertai gejala klinis akut maupun kronik ${ }^{9}$. Hiperglikemia pada penderita diabetes mellitus yang tidak terkontrol menyebabkan filtasi glomerulus pada ginjal mengandung lebih banyak glukosa daripada yang dapat direabsorpsi sehingga terjadi glukosuria. Glukosuria terjadi jika kadar glukosa darah melebihi $180 \mathrm{mg} / \mathrm{dL}$ atau yang disebut dengan ambang ginjal untuk glukosa

Komplikasi yang terkait dengan diabetes meningkatkan resiko infeksi, tingginya kadar glukosa didalam darah, jaringan, dan urine ${ }^{7}$. Pemeriksaan glukosa dalam urine atau disebut glukosuria sering dilakukan sebagai pemeriksaan pelengkap pada pemerikaan screening dan pemantauan penderita Diabetes

Mellitus. Glukosuria dapat dibuktikan dengan Uji Benedict dan Uji Carik Celup. Pemeriksaan glukosuria dengan uji benedict dapat dilakukan dengan biaya yang lebih ekonomis. Berdasarkan hasil penelitian yang dilakukan oleh Gunawan (2016), pemeriksaan glukosuria uji Benedict mempunyai kesesuaian yang cukup baik dengan Glukotes Carik Celup yaitu sebesar 77,5\%. Hal tersebut berarti Uji Benedict masih relevan atau valid digunakan untuk deteksi glukosuria sebagai usaha penapisan penderita tersangka Diabetes mellitus.

Laporan dari data Riset Kesehatan Dasar 2018 menyebutkan bahwa terjadi peningkatan angka prevalensi nasional penyakit diabetes mellitus untuk penduduk umur $\geq 15$ tahun yakni dari 1,5\% pada tahun 2013 dan menjadi 2,0\% pada tahun 2018. Sedangkan untuk wilayah NTB sendiri mencapai 1,6\%. Jumlah pasien penderita diabetes mellitus yang ada di Puskesmas Narmada Kabupaten Lombok Barat tahun2018 mencapai 262 orang. Berdasarkan latar belakang tersebut, maka perlu dilakukan penelitian mengenai hubungan antara kandidiasis urine pada wanita penderita diabetes mellitus dengan nilai positivitas glukosuria di wilayah kerja Puskesmas Narmada. 


\section{Jurnal Analis Medika Biosains (JAMBS)}

Vol.8, No.2, September 2021, pp. 92 - 98

ISSN: 2656-2456 (Online)

ISSN: 2356-4075 (Print)

\section{Metode Penelitian}

Penelitian ini merupakan penelitian Survei Analitik yaitu penelitian yang bertujuan untuk mengetahui seberapa jauh kontribusi faktor risiko tertentu terhadap adanya suatu kejadian tertentu (efek) dari analisis korelasi. Rancangan penelitian yang digunakan adalah Cross Sectional, dimana dinamika korelasi antara faktor-faktor risiko dengan efek dipelajari dengan cara pendekatan, observasi atau pengumpulan data sekaligus pada suatu saat (point time approach. Teknik pengambilan sampel yang digunakan dalam penelitian ini adalah Purposive Sampling yaitu penelitian yang didasarkan pada suatu pertimbangan tertentu yang dibuat oleh peneliti sendiri, berdasarkan ciri atau sifat-sifat populasi yang sudah diketahui sebelumnya. Adapun sampel yang digunakan dalam penelitian, yaitu memenuhi beberapa kriteria inklusi dan eksklusi. Kriteria inklusi sampel yaitu wanita dewasa berusia $\geq 30$ tahun, penderita diabetes mellitus, urine yang digunakan adalah urine sewaktu, dan bersedia menjadi subjek penelitian. Sedangkan kriteria eksklusi sampel meliputi wanita hamil,edang dalam keadaan sakit berat, sedang dalam keadaan haid.

\section{Hasil Penelitian dan Pembahasan}

Pemeriksaan Glukosuria (glukosa urine) diperiksa menggunakan metode benedict dapat dilihat pada gambar 1 berikut :

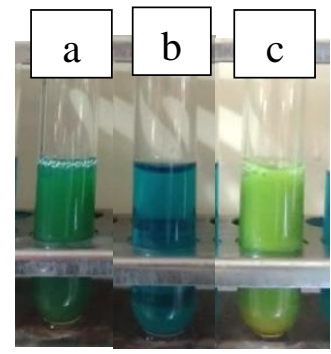

Sumber : Dokumentasi pribadi, 2019

Gambar 1. Hasil Pemeriksaan

Glukosuria Metode Bennedict, (a)

hasil negatif, (b) hasil positif 1, (c)

hasil positif 2

Pada gambar 1, hasil negatif menunjukkan tidak adanya perubahan warna pada larutan benedict sebelum dan setelah pemanasan. Sedangkan pada hasil positif menunjukkan adanya perubahan warna menjadi hijau pada positif $1(+1)$ dan menjadi kuning pada positif $2(+2)$. Data hasil pemeriksaan glukosuria dapat terlihat pada tabel 1.

Tabel 1.Hasil pemeriksaan Glukosuria menggunakan metode Bennedict

Glukosuria Jumlah Persentase

(\%)

\begin{tabular}{ccc} 
Negatif (-) & 13 & 54,2 \\
Positif (+1) & 8 & 33,3 \\
Positif (+2) & 3 & 12,5 \\
\hline Total & 24 & 100,0 \\
\hline
\end{tabular}




\section{Jurnal Analis Medika Biosains (JAMBS)}

Vol.8, No.2, September 2021, pp. 92 - 98

ISSN: 2656-2456 (Online)

ISSN: 2356-4075 (Print)

Berdasarkan tabel 4.2 menunjukkan bahwa hasil negatif (-) uji glukosuria dengan metode benedict didapatkan paling banyak yaitu sebanyak 13 sampel (54,2\%), positif (+2) paling sedikit yaitu sebanyak 3 sampel $(12,5 \%)$.

Hasil pemeriksaan Kandidiasis urine yang diamati dengan metode mikroskopis pada sedimen urine dapat dilihat pada gambar 2 berikut
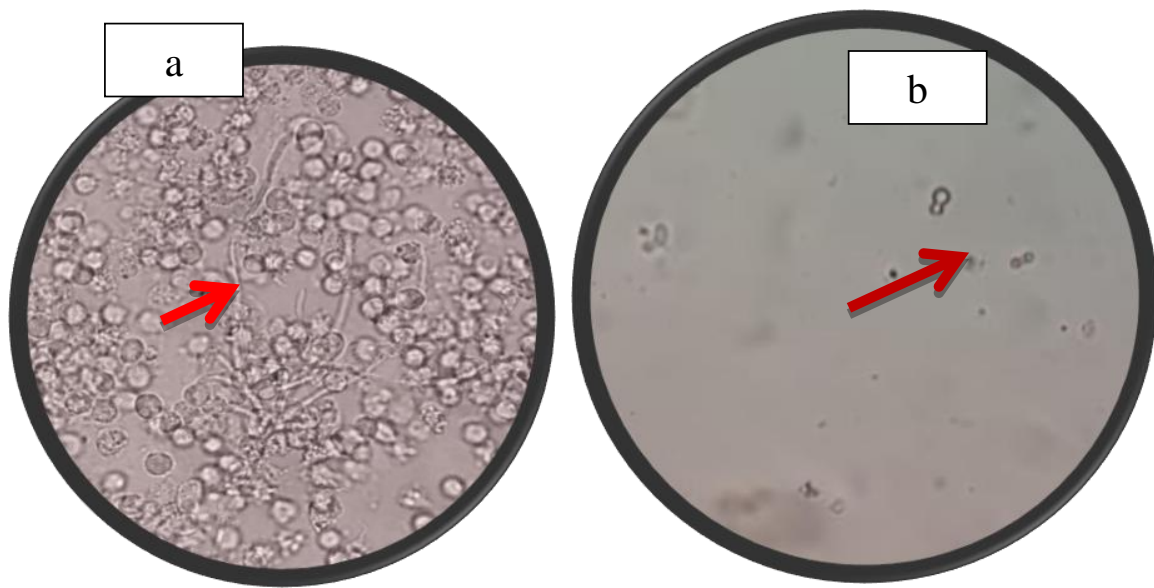

Sumber : Dokumentasi Pribadi, 2019

Gambar 2. Hasil Pemeriksaan

Kandidiasis, (a) Hifa jamur Candida,

(b) sel ragi jamur Candidida

Berdasarkan gambar 2a diatas, menunjukkan adanya hifa jamur Candida albicans, yang berbentuk panjang dengan sisi parallel. Sedangkan pada gambar $2 \mathrm{~b}$ merupakan sel ragi (blastospora) yang bagiannya terdiri dari sel induk (body) dan tunas (budding). Data hasil pemeriksaan kandidiasis dapat terlihat pada tabel 2 berikut

Tabel 2 Hasil Pemeriksaan Kandidiasis

\begin{tabular}{ccc}
\hline Kandidiasis & Jumlah & $\begin{array}{c}\text { Persentase } \\
(\%)\end{array}$ \\
\hline Positif & 3 & 12,5 \\
Negatif & 21 & 87,5 \\
\hline Total & 24 & 100,0 \\
\hline
\end{tabular}

Berdasarkan tabel 2 menunjukkan bahwa keberadaan jamur Candida albicans penyebab kandidiasis pada wanita penderita diabetes mellitus dari 24 sampel hanya didapatkan pada 3 sampel (12,5\%), selain itu tidak terdapat hifa maupun spora jamur Candida albicans pada sedimen urine yang diamati.

Hubungan antara kandidiasis pada urine wanita penderita diabetes mellitus dengan nilai positivitas glukosuria,dapat diketahui dengan melakukan analisis data dengan uji statistik Chi square pada program SPSS. Adapun hasil uji Chi square dapat dilihat pada tabel 3. 
Jurnal Analis Medika Biosains (JAMBS)

Vol.8, No.2, September 2021, pp. 92 - 98

ISSN: 2656-2456 (Online)

ISSN: 2356-4075 (Print)

Tabel 3 Hasil Uji Chi square

\begin{tabular}{|c|c|c|c|c|c|c|c|}
\hline \multirow{2}{*}{$\begin{array}{l}\text { Gluko- } \\
\text { suria }\end{array}$} & \multicolumn{4}{|c|}{ Kandidiasis } & \multirow{2}{*}{$\Sigma$} & \multirow{2}{*}{$\%$} & \multirow{2}{*}{$\mathbf{P}$} \\
\hline & Pos & $\%$ & Neg & $\%$ & & & \\
\hline Negatif & 0 & 0 & 13 & 54,2 & 13 & 54,2 & \\
\hline $\begin{array}{l}\text { Positif } \\
(+1)\end{array}$ & 1 & 4,2 & 7 & 29,2 & 8 & 33,3 & \\
\hline $\begin{array}{l}\text { Positif } \\
(+2)\end{array}$ & 2 & 8,3 & 1 & 4,2 & 3 & 12,5 & 0,007 \\
\hline Jumlah & 3 & 12,5 & 21 & 87,5 & 24 & 100,0 & \\
\hline
\end{tabular}

Signifikan $\mathrm{p}<0,05$

Berdasarkan hasil uji statistic dengan metode Chi square pada tabel 4.4 diatas, hasil pemeriksaan glukosuria dan kandidiasis urine menunjukkan nilai probabilitas $0,007<\alpha=0,05$ artinya ada hubungan antara kandidiasis pada urine wanita penderita diabetes mellitus dengan nila positivitas glukosuria di wilayah kerja Puskesmas Narmada.

Pemeriksaan glukosuria metode benedict bersifat semi kuantitatif. Prinsip pemeriksaannya yaitu glukosa akan mereduksi kuprisulfat dalam reagen menjadi kupro sulfat yang disertai dengan reaksi perubahan warna benedict sesuai dengan kadar glukosa yang terlarut dalam urin. Semakin banyak kadar glukosa urine maka akan semakin banyak kupri sulfat yang direduksi menjadi kupro sulfat, sehingga warna dari reagen benedict akan semakin merah. Hal ini menjadi dasar dalam interpretasi hasil pemeriksaan glukosuria metode benedict dimana setiap grade menunjukan perkiraan kadar glukosa urine. Hasil positif ditunjukkan dengan adanya kekeruhan dan perubahan warna dari biru menjadi hijau kekuningan sampai merah bata.

Hasil analisis Chi square pada tingkat kepercayaan $95 \%$ menunjukkan adanya hubungan yang signifikan/ bermakna. Hal ini menunjukkan bahwa kandidiasis pada urine wanita penderita diabetes mellitus berbuhungan dengan nilai positivitas glukosuria. Namun, berdasarkan penelitian yang telah dilakukan sebelumnya oleh Klause Rave dkk, yang meneliti tentang ekskresi glukosa di ginjal sebagai fungsi dari konsentrasi glukosa darah, bahwa semakin tinggi kadar glukosa darah maka akan meningkatkan pengeluaran glukosa melalui ginjal atau yang disebut juga dengan glukosuria ${ }^{18}$. Hal tersebut berarti penderita diabetes mellitus yang memiliki kadar gula darah $\geq 200 \mathrm{mg} / \mathrm{dL}$ akan positif pada pemeriksaan glukosuria. Sedangkan dalam penelitian ini, sebanyak 13 sampel masih negatif terhadap pemeriksaan glukosuria walaupun sampel yang digunakan merupakan penderita diabetes mellitus dan memiliki kadar gula darah diatas batas ambang toleransi ginjal.

Dari hasil wawancara singkat yang telah dilakukan peneliti terhadap 24 responden, ternyata ada beberapa responden yang memiliki kadar gula darah sewaktu <200 mg/dL. Hal tersebut menyebabkan biasnya hasil penelitian, sehingga walaupun secara statistik menyebutkan kandidiasis pada urine wanita penderita diabetes mellitus berhubungan dengan nilai positivitas glukosuria, namun secara klinis keduanya tidaklah berhubungan. Seharusnya kadar gula darah pada penderita diabetes mellitus yang digunakan sebagai responden $\geq 200 \mathrm{mg} / \mathrm{dL}$ dan positif pada pemeriksaan glukosuria.

Journal homepage: http://jambs.poltekkes-mataram.ac.id/index.php/home/index 


\section{Jurnal Analis Medika Biosains (JAMBS)}

Vol.8, No.2, September 2021, pp. 92 - 98

ISSN: 2656-2456 (Online)

ISSN: 2356-4075 (Print)

Kadar glukosa dalam urine yang berlebih menyediakan makanan untuk pertumbuhan jamur. Pertahanan imunitas penderita Diabetes mellitus dan $\mathrm{pH}$ urine yang rendah juga merangsang pertumbuhan jamur. Meningkatnya frekuensi buang air kecil pada penderita diabetes mellitus membuat daerah genetalia yang lebih lembab dimana jamur dapat tumbuh subur. Sehingga pada saat pemeriksaan urine penderita Diabetes Mellitus dapat ditemukan jamur Candida albicans. Hal ini dapat disebabkan karena jamur ikut terbawa bersama urine yang dikeluarkan

Berdasarkan uji penyaring menggunakan pemeriksaan sedimentasi urine yang dilakukan terhadap 24 sampel urine wanita penderita diabetes mellitus di Puskesmas Narmada, ditemukan 3 sampel urine yang positif terinfeksi Candida albicans. Namun kondisi tersebut belum menggambarkan faktor yang berpengaruh terhadap tinggi atau rendahnya tingkat infeksi Candida albicans pada wanita penderita diabetes mellitus, sehingga perlu dilakukan penelitian lanjutan karena dimungkinkan adanya pengaruh hygiene sanitasi terhadap tingkat kandidiasis, dari hasil pemeriksaan urine wanita penderita diabetes mellitus tidak hanya menggunakan tes penyaring tetapi dilanjutkan dengan kultur urine sehingga memberikan hasil yang lebih akurat dengan waktu dan jumlah sampel yang lebih banyak, sehingga hasil yang diharapkan dapat lebih representatif.

\section{Kesimpulan}

Secara statistik, ada hubungan antara kandidiasis pada urine wanita penderita diabetes mellitus dengan nilai positivitas glukosuria di wilayah kerja Puskesmas Narmada. Namun bila dikaji secara klinis, maka keduanya tidaklah berhubungan, sebab kadar gula darah pada penderita diabetes mellitus yang $\geq 200 \mathrm{mg} / \mathrm{dL}$ merupakan ambang batas ginjal yang seharusnya dapat menyebabkan timbulnya glukosuria, sehingga apabila glukosurianya negatif maka kandidiasisnya pun akan negatif.

\section{Daftar Pustaka}

Abrori., Andri Dwi Hernawan., \& Ermulyadi. (2017). Faktor yang Berhubungan dengan Kejadian Keputihan

Patologis Siswi SMAN 1 Simpang Hilir Kabupaten Kayong Utara. Unnes Journal of Public Health, 6(1).

Badan Penelitian dan Pengembangan Kesehatan Kementerian Kesehatan RI. (2018). RISKESDAS 2018.

Clayton, C. (1996). Keputihan dan Infeksi Jamur Candida lain, Seri Kesehatan Wanita. Jakarta : Arcan

Danuyanti, I. G. A. N. (2014). Pola Hygiene Sanitasi Wanita Penderita Diabetes Mellitus pada Kasus Kandidiasis Di Wilayah Kerja Puskesmas Di Kabupaten Lombok Barat. Media Bina Ilmiah, 8(5), 3844.

Danuyanti, I. G. A. N., \& dkk. (2013). Prevalensi Kandidiasis Berdasarkan Hasil Pemeriksaan Sedimen dan Kultur urine Wanita Penderita Diabetes Mellitus di Puskesmas Wilayah kabupaten Lombok Barat. Jurnal Analis Kesehatan.

Gandasoebrata, R. (2008). Pemeriksaan Urine, Penuntun Laboratorium Klinik. Jakarta : Dian Rakyat

Getas, I. W., IGAN Danuyanti., \& Ida Ayu Wayan W. (2013). Hubungan Perilaku Hygiene dan Sanitasi 


\section{Jurnal Analis Medika Biosains (JAMBS)}

Vol.8, No.2, September 2021, pp. 92 - 98

ISSN: 2656-2456 (Online)

ISSN: 2356-4075 (Print)

Terhadap Tingkat Kandidiasis dari Hasil Pemeriksaan Urine Wanita Penderita Diabetes Mellitus di

Puskesmas Narmada Kecamatan Narmada, Lombok Barat. Media Bina Ilmiah, 7(5), 5-10.

Gunawan, Fakhri F. (2016). Kesesuaian Hasil Pemeriksaan Glukosuria Uji Benedict dan Glukotes Carik

Celup Urin Penderita Diabetes Mellitus. Thesis. Bandung : Universitas Kristen Maranatha

Hernawati, S. (2007). Hubungan Kadar Glukosa Darah dengan pertumbhan Candida albicans pada penderita

Diabetes Mellitus. Indonesian Journal of Dentistry.

Irianto, Koes. (2013). Parasitology Medis (Medical Parastology). Bandung : Alfabeta

Kuswadji. (2002). Ilmu Penyakit Kulit dan Kelamin. Jakarta : Fakultas Kedokteran UI Press

Murray, R., D. Granner., \& V. Roodwell. (2009). Biokimia Harper Edizi 27. Jakarta : Penerbit Buku

Kedokteran EGC

Notoatmodjo, S. (2012). Metodologi Penelitian Kesehatan. Jakarta: PT Rineka Cipta.

Ramaiah, Savitri. (2007). Diabetes : Cara Mengetahui gejala Diabetes dan Mendeteksinya Sejak Dini. Jakarta : Bhuana Ilmu Populer

Rani, T. S., \& Wantini, S. (2016). Gambaran Jamur Candida albicans Dalam urine Penderita Diabetes Mellitus di RSUD Jendral Ahmad Yani Kota Metro, 5(1), 0-4.

Rave K, Nosek L, Posner J, Heise T, Roggen K, Van H. (2006). Renal Glucose Excretion As A Function Of Blood Glucose Concentration In Subject With Type 2 Diabetes Result Of A Hyperglycaemic Glucose Clamp Study. Nephrol Dial Transplant, 21(8) : 166-71

Tasik, N. L., Grace M.K., \& Renate T.K. (2016). Profil kandidiasis vulvovaginalis di Poliklinik Kulit dan Kelamin RSUP Prof. Dr. R. D. Kandou Manado periode Januari - Desember 2013. Jurnal E-Clinic (eCl), 4(1), 207-214. 